\title{
Challenges and opportunities for mine closure planning in Indonesia
}

\author{
S. Finucane Bioscope Environmental Consulting Pty Ltd, Australia \\ P. Soeprapto PT Newmont Nusa Tenggara, Indonesia \\ K. Wiryanto Mine Closure Observer, Indonesia \\ T. Ainscough S7 Consulting Pty Ltd, Australia
}

\begin{abstract}
There has been increased focus on mine closure planning and implementation in Indonesia in recent years due to a range of company initiatives and government triggers such as the introduction of government regulations regarding mine reclamation and closure. However, the Indonesian mining industry faces continuing challenges in mine closure as a result of past practices as well as contemporary issues. These challenges relate not only to the country's regulatory framework, but also to the complexity of environmental, cultural and socio-economic issues in Indonesia today.

Until 2008, there had been little guidance on government expectations for mine closure in Indonesia other than limited reference in a Contract of Work agreement between the Government of Indonesia and a mining company. A process to address this deficiency was triggered by the Indonesian Government in 2000 and culminated in the issuance of a ministerial decree regarding reclamation and mine closure in 2008 and a government regulation regarding the same in 2010. Mining companies have been working to meet these requirements, with varying degrees of success.

In addition to regulatory considerations, mining companies operating in Indonesia face myriad technical, environmental, socio-economic, cultural challenges in relation to mine closure. This is not surprising given the country's geographic, demographic and ecological diversity, which gives rise to widely varying approaches to the management of these issues. Drawing on examples from a number of mining operations, this paper provides an overview of some of the key mine closure planning challenges and opportunities currently facing mining companies in Indonesia.
\end{abstract}

\section{Introduction}

Over the past decade, there has been increased focus on mine closure planning and implementation in Indonesia. Significant progress has been made, but the Indonesian mining industry faces continuing challenges in mine closure as a result of past practices as well as contemporary issues. These challenges relate not only to the country's legislative framework, but also to the complexity of environmental, cultural and socio-economic issues in Indonesia today. This complexity is strongly influenced by the diversity of natural, cultural and political conditions present within the country. Indonesia is the world's largest archipelagic state with more than 17,500 islands. It has the most volcanoes in the world, the world's second largest tropical forest and the greatest marine biodiversity on the planet. It is also the world's fourth most populous nation, with more than 300 ethnic groups and more than 250 languages spoken throughout the country (Bureau of East Asian and Pacific Affairs, 2011).

Indonesia is a republic comprising 33 provinces, two special regions and the special capital city district of Jakarta. Following the introduction of regional autonomy (decentralisation) on 1 January 2001, regencies and municipalities have become the key administrative units responsible for providing most government services rather than the central (national) government. In addition to myriad national, regional and local laws and regulations, the country is party to a number of international agreements relating to climate change, protection of the ozone layer, biodiversity, tropical timber, desertification, wetlands, endangered species and hazardous wastes. 
The geographic, legislative, political, environmental, cultural and socio-economic diversity that characterises Indonesia strongly influences the way in which mining companies plan, operate and close their projects. Recent development of regulations by the Government of Indonesia (GoI) has provided guidance in relation to mine reclamation and closure, but there are still many issues that need to be addressed. The key issues include:

- The formative nature of the regulatory framework for mine closure in Indonesia.

- Difficulties in setting achievable success or closure criteria, including the lack of spatial plans for almost all regions.

- The capacity and priority of local and regional governments to manage implementation of the mine closure regulation prior to, during and following mine closure.

- Sustaining communities post-closure and avoiding dependence.

- The impacts of artisanal and illegal miners and illegal loggers on a closed mine site.

- Managing stakeholder expectations.

These issues are discussed below.

\section{Legislative framework for mine closure in Indonesia}

Early legislation and agreements relating to mining in Indonesia had little or no content relating to closure. Closure obligations identified in the Contract of Work (CoW) agreement between the GoI and a mining company tended to be limited to a requirement to prepare a closure plan at least 12 months prior to the cessation of processing operations. The GoI recognised the need to remedy this deficiency in time for the expected closures of a number of major mines in 2002 and 2004, and in 2000 it initiated a process to develop closure legislation (Cesare and Maxwell, 2003).

The initial phases in the development of mine closure legislation included the use of open fora to obtain input from key stakeholders. To prepare for these meetings, 21 representatives from seven mining companies operating across Indonesia met on 5 October 2000 to review the current status of ongoing projects and to discuss common closure issues. Key issues were identified as the lack of instructions and guidance from Government regarding mine closure and end point (closure) criteria, the engagement and participation of Non Government Organisations (NGOs) in the mine closure process, and the desirability of a common industry approach for workforce redundancy practice and negotiations (Cesare and Maxwell, 2003).

The mining companies represented at the initial forum are listed in Table 1 and included PT Nusa Halmahera Minerals (PT NHM), PT Newmont Pacific Nusantara (PT NPN), and PT Kelian Equatorial Mining (PT $\mathrm{KEM}$ ). As a result of the forum, these seven companies agreed to establish the Industry Mine Closure Steering Committee (IMCSC).

Table 1 IMCSC companies and their projects (Source: Cesare and Maxwell, 2003)

\begin{tabular}{lll}
\hline Company & Parent Company & Project and Commodity \\
\hline PT Arutmin Indonesia & BHP & Senakin and Satui (coal) \\
PT Barisan Tropical Mining & Laveton-Durban & Rawas (gold) \\
PT Indo Muro Kencana & Aurora & Mt Muro (gold) \\
PT Kelian Equatorial Mining & Rio Tinto & Kelian (gold) \\
PT Newmont Pacific Nusantara & Newmont & Batu Hijau (copper-gold) and Minahasa (gold) \\
PT Nusa Halmahera Minerals & Newcrest & Gosowong (gold) \\
PT Prima Contracting & Prima Lirang Mining & Wetar (gold) \\
\hline
\end{tabular}

The IMCSC's first opportunity to engage in discussions with the Indonesian Department of Energy and Mineral Resources (DEMR) was a DEMR workshop on mine closure held on 24 October 2000 which 
resulted in recommendations being made in relation to mine closure planning and financing, CoW agreements and the social aspects of mine planning. Subsequently, the IMCSC produced a guideline for mine closure for the DEMR to provide the industry perspective on the scope required for the proposed legislation. The guideline closely paralleled the Strategic Framework for Mine Closure produced by the Australian and New Zealand Minerals and Energy Council (ANZMEC) and Minerals Council of Australia (MCA) in 2000 (ANZMEC and MCA, 2000), and addressed mine closure planning, implementation and standards as well as stakeholder engagement, financial provisioning and relinquishment (Cesare and Maxwell, 2003).

Discussions between the DEMR and IMCSC continued until these parties reached agreement on the final form of the proposed mine closure regulations on May 23, 2001. The Indonesian Government had been aiming to issue the new closure legislation quickly to ensure that a unified regulation for mine closure was in place nationwide prior to the implementation of regional autonomy in January 2001, but this deadline had passed and regional autonomy was already in place when agreement was reached on the draft regulations, so it was suggested that these be issued as a presidential decree to compel the now autonomous regions to embrace the regulations and ensure that a common standard was achieved across Indonesia. However, instead of a presidential decree, when it was finally issued, the first Indonesian regulation regarding mine reclamation and closure was a ministerial decree (Ministerial Regulation Number 18 Year 2008 Regarding Reclamation and Mine Closure). This has now been replaced by Government Regulation Number 78 Year 2010 regarding Reclamation and Post Mining which has stronger enforcement power than a ministerial decree.

Despite the absence of mine closure regulations that existed prior 2008, PT Newmont Minahasa Raya (PT NMR) started to draft its Mine Closure Plan for the Minahasa gold mine in North Sulawesi in consultation with its stakeholders. These included the surrounding community, local government and central government. In the absence of government regulations on mine closure, the company referred to its CoW agreement, environmental impact assessment documentation (known as Analisis Mengenai Dampak Lingkungan or AMDAL), and prevailing laws and regulations on mining, environment and forestry both at central and local levels. The draft closure plan was refined following consultation with the Ministry of Energy and Mineral Resources (MEMR) and then a larger stakeholder forum including other related ministries, business, local representatives of surrounding mining areas, and community groups. The Minahasa mine closure plan was finally approved by the MEMR on 31 December 2002.

The 2010 mine reclamation and closure regulation encompasses four principal elements, these being (i) the preparation by mining companies of reclamation and closure plans that incorporate success criteria, (ii) the review and approval of the plans by regional governments, (iii) the funding and implementation of the plans by the mine owners, and (iv) provision of an alternative means for implementing the plans if the mine owners fail to do so (Sullivan, 2011). The regulation provides firmer guidance on reclamation and mine closure aspects for both government and mining companies than existed previously, but a number of concerns have been raised. These include the need for clarification on the mechanism and schedule for calculating and lodging mine closure guarantees (bonds), and the establishment of success criteria for final mine closure sign-off and return of the closure guarantees. In addition, there is a need to clarify the role of local/regional government officials and inspectors in coordinating implementation of the regulation (Soeprapto, 2011) (Section 4). It has even been commented that the 2010 regulation places "excessive burdens on mining companies while completely ignoring the practical inability of most Regional Governments to be able to properly supervise the contemplated system of mining environment protection and management" (Sullivan, 2011). Further consultation and relationship building between mining companies and local government agencies will assist in clarifying and refining regulatory requirements, assist in building local government capacity, and increase the likelihood of achieving the intent of the regulation to improve environmental protection and management.

\section{$3 \quad$ Setting success criteria}

The way in which mining companies define closure objectives and success criteria is strongly influenced by the guidance provided by regulatory agencies. In Indonesia, this guidance is provided primarily through key mining and forestry legislation and regulations, regional spatial plans and AMDAL. 
One of the main challenges facing PT NMR in developing a workable and enforceable mine closure plan for Minahasa was the limited regulations that can be used as reference to determine success criteria. Further, no spatial plan existed at either central or local government levels at that time. Consequently, the company developed its own success criteria through a process that included consideration of criteria applied to projects outside of Indonesia. In 2009, a team of representatives from the Indonesian ministries of Energy and Mineral Resources, the Environment and Forestry (as well as from other forestry groups) assessed progress of mine reclamation and closure at Minahasa and awarded it 93 out of 100 in terms of successful reclamation. Consequently, it is considered that PT NMR has fulfilled its reclamation obligations at this site (Newmont, 2010).

The Indonesian 2010 mine closure regulation requires that reclamation and closure plans address principles related to environmental protection and management, occupational safety and health, and mineral and coal conservation. The regulation also requires that these plans be formulated on the basis of an approved AMDAL or other environmental documents and include success criteria, but there is no further guidance on what these should address or how these should be developed. While this lack of guidance may be seen by some as a problem, in fact it provides companies with an opportunity to define criteria that best suit their projects.

Where the mine operates within designated forest areas, it does so under a Pinjam Pakai land agreement (forest lease). Therefore, in addition to fulfilling its closure obligations defined in the mining company's $\mathrm{CoW}$, it needs to comply with reclamation and closure requirements defined in the Pinjam Pakai. This agreement obliges a company to remove all assets from the forest lease area upon closure and to undertake reforestation to the original condition of the land. However, local governments and communities often expect and demand to obtain benefit from the infrastructure developed by a mining company (particularly roads) and sometimes wish to develop cleared areas for cultivation. For example, PT NMR experienced considerable pressure from the local community to maintain a main access road from Ratatotok to the Mesel mine on Sulawesi island, but the company was obliged to demolish the sealed road after it had rehabilitated its camp and office sites. However, after consultation with the Department of Forestry, the company assisted the community and regional government in requesting a dispensation or a new Pinjam Pakai for the road on the basis that a complete settlement had already been established in the forest hinterland of the mine.

The Pinjam Pakai forest lease usually specifies that the original forest classification be retained during and following mining. Clearly, a Pinjam Pakai agreement is intended to facilitate the temporary use of land prior to reforestation and is not intended to be an approval for forest conversion. This allows a mining company to define success criteria relevant to the forest classification for that site. However, in some instances, it is appropriate to change the forest classification. The forest within the Kelian lease area in Kalimantan was originally classified as Limited Production Forest which allowed for selective logging of hardwood timbers from the primary rainforest. However, to protect rehabilitated waste dumps and permanent engineered structures following site closure, it was agreed that the area instead be classified as Protected Forest following the cessation of mining (McGuire, 2003a).

A mining company's primary responsibility is to execute its obligations for mine closure and reclamation under the CoW agreement, all relevant mining legislation and the Pinjam Pakai forest lease. Often, this means that local government desires tend to be overlooked unless defined in spatial plans. The GoI is multitiered, with each of the respective governments having the authority to draft socio-economic development plans according to the National Development Planning System (Law No 25 Year 2004) and spatial plans according to the Spatial Planning Law (Law No 26 Year 2007), the National Spatial Plan Regulation (Government Regulation 26 of 2008), and the (Regional) Spatial Planning Regulation (Government Regulation 15 of 2010). Development in the country centres on these plans as they define strategies that seek to achieve security, sustainability and economic viability in the use of land and land function in Indonesia (Anon, 2011). The post-mining land use defined in the AMDAL or other relevant environmental documentation should align with the land function defined in spatial plans for the region in which the project is located, but these have not been developed for all regions. When PT Newmont Nusa Tenggara (PT NNT) developed the mine closure plan for the Batu Hijau gold mine on Sumbawa island, no spatial plan was in place at the kabupaten or provincial levels and there was no discussion on project assets on land outside of the Pinjam Pakai. Consequently, decisions still need to be made on the fate of the power stations and port 
facilities which are on land outside the Pinjam Pakai though it could reasonably be expected that these could be sold or donated to a third party.

Post-mining land uses and success criteria also need to reflect the needs, priorities and values of the local community. However, the diverse nature of communities means that reaching alignment can be difficult. An AMDAL for a mining project usually specifies the post-mining land use (often as a return to forest), but often this does not address land use planning for local communities so opportunities to provide benefit for these communities are lost. At Minahasa, PT NMR addressed this by providing opportunity to channel economic benefit to surrounding stakeholders by, for example, converting former mining offices to local government offices, donating housing for villages, donating the significant income derived from scrap steel to local Yayasan people, and implementing Corporate Social Responsibility (CSR) commitments to assist in sustaining new economic activities. PT NNT has also defined a community development program to ensure people's empowerment and capacity building and considers it appropriate that such a program (with a timeline) be incorporated into the closure plan given the high social dynamics taking place in the locality.

Typically, post-mining land use and success criteria for mining projects in Indonesia and other countries are defined based on pre-mining site conditions. This approach does not allow for consideration of the conditions that may exist in the future, particularly in relation to climate. Indonesia is particularly vulnerable to the effects of climate change, with effects likely to include rising sea levels and erosion of coastal areas, an increase in the frequency and intensity of extreme weather events, the extinction of certain species and the spread of vector-borne diseases (Bureau of East Asian and Pacific Affairs, 2011). The need to address climate change in closure planning is now required by a number of regulatory authorities such as Western Australia's Environmental Protection Authority and Department of Mines and Petroleum (who have issued guidelines that require that local climate conditions and projected future climate change be addressed in mine closure plans), but the Indonesian government's approach to this aspect is still being developed.

\section{$4 \quad$ Local and regional government issues}

As indicated in Section 1 of this paper, regional autonomy was introduced in Indonesia on 1 January 2001. Often referred to as 'decentralisation', regional autonomy resulted in responsibility for the provision of most government services being transferred from the central government to regencies and municipalities. In most cases, it was expected that regulatory control over mining and mine closure would also shift from the central government to regional governments. However, there is often a lack of confidence in local communities and elsewhere about local government's ability and priority to manage a mine site once a mining company has relinquished its leases. This provides an opportunity for capacity building within government. This is not to suggest that a mining company should take significant or sole responsibility for ensuring that local, regional or central government is sufficiently skilled and resourced for this purpose, but that an opportunity exists for mining companies to contribute to this process, if it chooses to do so. For example, at Kelian, some aspects of local health programs were transferred to local government, and PT KEM and Rio Tinto committed sufficient funding to meet the administrative costs of these programs in perpetuity if well managed (McGuire, 2003a).

One of the issues arising from regional autonomy has been a lack of clarity regarding the roles and authority of the various levels of government in relation to mine closure (Cesare and Maxwell, 2003). This is exacerbated by differing levels of knowledge in interpreting laws and regulations at different levels of government. This was recognised during the closure planning process for the Minahasa gold mine (which occurred in the period between decentralisation and the introduction of the mine closure regulations), resulting in PT NMR establishing a mine closure team that included relevant central and local government officials to assist in interpreting laws and regulations related to the autonomy authorities and clearly defining the roles of these authorities. It was hoped that the government regulation on mine reclamation and closure would provide clarity regarding government roles and responsibilities as it was introduced well after decentralisation, but it has not done so and there is still a need to clarify and socialise the role of local/regional government in coordinating implementation of the regulation (Soeprapto, 2011), and to ensure that these agencies have the human and technical resources required to evaluate mine closure plans in an informed and meaningful manner (Sullivan, 2011). 
Mine closure in Indonesia, as with many other countries, can have a devastating financial impact on governments, particularly at a local level. Cessation of production prior to mine closure is often the first step in a drastic reduction of local government revenues which is often followed closely to a reduction in the general level of support that a local government provides to the mining company. This is unfortunate as the same period can be marked by an increase in issues on site (such as a reduction in local employment and retrenchments) that need to be managed cohesively by the mining company and local government. In the absence of an integrated management approach, the mining company often goes through a fairly painful withdrawal following mine closure and may find itself facing ambit claims over local customary land use as well as the spread of misinformation leading to serious impacts on the company's international reputation. This period can also see an "unholy alliance" develop between locally disaffected communities and sometimes also between communities and local governments that is fuelled willingly and enthusiastically by anti-mining NGOs, and which can result in fictitious claims of environmental and criminal activities by the mining company such as those brought against PT NMR in the Buyat Bay case (an alleged environmental pollution case for which the court decision later demonstrated that the company had not committed any environmental law violations).

Solutions for this situation are varied, but can be difficult to implement. Some sites have established trust funds to provide local governments with some post-closure revenues. However, another favourable outcome would be for the mining company to provide a legacy through direct development of an alternative industry which may in some way continue to provide returns for local government through direct and indirect taxes. This opportunity is discussed further in Section 5.

\section{$5 \quad$ Sustaining local communities}

It is almost impossible for local communities not to become dependent on the income, employment, infrastructure, facilities and other benefits provided by a mine as these become part of the fabric of nearmine communities. These include direct employment through the mine and its contractors, indirect employment, benefits to community through taxes and royalties paid to local government by the company, small and medium business opportunities, community development programs (such as health, education and local infrastructure) and contributions to sporting and other social endeavours in local communities. Consequently, closure of the site has significant impacts on the well-being of these communities, particularly where little competitive industry exists and government and communities lack the resources and processes to develop suitable alternatives.

Mine closure follows a steady and sometimes rapid reduction in direct and indirect employment, and an unravelling of the "multiplier effect". Many traders and contractors come to a region because of opportunities presented by mining development and then leave as these opportunities disappear. However, PT KEM found that most local people who had in some way become dependent on the Kelian mine intended to remain in the area after mine closure. The company recognised that certain economic hardship would occur as a result of mine closure and that any threats of uncontrollable hardships or perceived decline in wealth could place undue strains on relationships with and between villages (McGuire, 2003a). To address these concerns the company initiated communications and training strategies to keep local communities informed and help them plan and adjust to the hardships of closure. Solutions to the problems of project dependency implemented by PT KEM included the provision of training to employees in such fields as economics, agriculture, motor mechanics and small business management and implementation of food security projects (McGuire, 2003a).

The 2010 Indonesian mine closure regulation requires that a site's closure plan address community development and empowerment, but many mining companies had been doing so long before it became compulsory. While there is a question around what real obligation a company has to "sustain" near-mine communities post-closure, if non-mining industries of relevance to local communities can be initiated by a mining company's community development strategy (rather than the provision of scholarships and less relevant education may have little benefit to the local community as recipients of this training often opt to leave the community to pursue further study or work in their chosen field), then these skill sets may have a more prolonged benefit to the community. In its current mine closure plan for Batu Hijau, PT NNT has outlined a community development plan that would cover continuation of existing community development programs. This involves a change in focus from infrastructure building to maintaining and handing over of 
infrastructures, funding and implementing capacity building programs and establishment of a trust fund. Programs and activities developed by PT NMR and aimed at increasing the capacity of local communities include the provision of initial capital for small scale businesses such as a bakery, mechanics shop, animal husbandry, seaweed farming, virgin coconut oil industry, traditional dried fish processing, and fish-catch industry/cold storage.

It is considered that the ethos of post-mining sustainability should permeate all current community development. However, this can be difficult to achieve when initiatives for community development and CSR are determined, in part or in full, by local government and communities who have short term (annual) objectives and aspirations and may find it difficult to sacrifice these in favour of longer term and post-closure objectives.

\section{$6 \quad$ Artisanal and illegal mining}

Artisanal mining has been recognised as a significant and important part of integrated rural development by a number of countries and development agencies such as the World Bank as it provides a cash-based input to rural areas which adds to and assists agricultural pursuits, strengthens economic infrastructure and assists in alleviating rural poverty (Chamid et al., 2000). However, this sector is perhaps better known for its high environmental costs and poor health and safety record, as outlined by Hentschel et al. (2002). In particular, uncontrolled artisanal mining at a mine site that has been rehabilitated and closed can create significant environmental and community risks.

It is considered that there is little or no risk of illegal or artisanal mining occurring at PT NMR's Mesel mine as the refractory ore at the mine cannot be processed by conventional artisanal mining methods. Similarly, there is only a small risk, if any of artisanal or illegal miners in the Batu Hijau region due to ore body characteristics. However, this is an ongoing problem at PT NHM's Gosowong gold mine on Halmahera island. Artisanal miners came into the PT NHM CoW area from adjacent islands in Indonesia once the presence of gold ore was discovered, as evidenced by the presence of an international miner operating in that area. Illegal mining focused primarily on the Toguraci pit and resulted in a range of environmental and community impacts. The presence of illegal miners has also been detrimental to achieving rehabilitation commitments with areas that had undergone progressive rehabilitation being destroyed or severely impacted.

Ore mined illegally at Toguraci and surrounding areas is processed at trommels in a way that (along with the illegal mining of the ore) is often undertaken with a low level of technical knowledge and skills, disregard for human safety and environmental health, and no government or other regulation (Limbong et al., 2002; NML, undated). At the completion of the process, the mercury used in ore processing is discarded at the trommel sites, which leads to a range of impacts including soil and water contamination, and health impacts. Consequently, PT NHM conducts a comprehensive environmental monitoring program in the catchment and adjacent Kao Bay, and also conducts community awareness programs (NML, undated). There is potential for the downstream pollution from artisanal mining and processing operations to continue after PT NHM closes the Gosowong mine if this is not managed effectively by Government or through other means, which poses a reputational risk for the company.

Artisanal miners and mining companies often have a different perception of the economic value of abandoned mine workings, waste rock dumps and Tailings Storage Facilities (TSFs) with the former seeing value in reworking closed mines in their search for any mineral perceived to have been left behind. At the Kelian mine, investigations by PT KEM indicated that the concentration of gold in the Namuk Tailings Dam (NTD) could not be mined and processed economically using any known industrial recovery technologies, but the artisanal mining community had reached a different conclusion, believing that the NTD contained significant gold that could cover their families' daily basic needs (Chamid et al., 2000). To reduce the risk of disturbance of the Kelian mine site following closure, particularly the creation of Protected Forest (McGuire, 2003a), PT KEM involved the local mining community in the decision-making process and conducted a verification program to determine the presence of mineable gold in the NTD.

The community verification program involved community leaders, Kampong leaders as well as traditional miners and followed PT KEM's safety and security standards and procedures. As a result of the program, it became clear that the gold in the NTD was not as easy to recover as river gold, with this understanding spreading to several communities. However, Chamid et al. (2000) indicate that PT KEM decided to allow 
community mining activities to sterilise the NTD prior to mine closure and that community rangers would monitor the proposed Protected Forest area to prevent adverse environmental activities.

There is concern that reputation risk associated with illegal miners could be transferred to the outgoing mining company, and that the company could be in some way held responsible or perceived to have responsibility for the environmental and social impacts of any artisanal/illegal mining that occurs following legal site closure. Cesare and Maxwell (2003) state that one of the clauses included in the final draft of the Indonesian mine closure decree developed in 2001 included allowance for mining companies to plan and implement closure while limiting their liability for damage resulting from the action of illegal miners and other third parties which adversely affect mine sites. However, this does not seem to have been included in the 2010 government mine closure regulation. This raises the question about the type of protection or exposure that mining companies have in relation to managing illegal/artisanal miners and closure. PT NMR's mine closure plan (which has been approved by the DEMR) includes a disclaimer about impacts that are not from PT NMR's operations, but this is in conflict with other legal requirements. In reality, PT NMR has rehabilitated not only its own operational disturbances, but also those from illegal mining of waste rock dumps, heap leach pad and other areas. Following these works, the DEMR's Director General - Mineral, Coal and Geothermal issued a decree in April 2011 accepting the company's closure efforts and now requiring that the company relinquish its $\mathrm{CoW}$.

\section{$7 \quad$ Managing stakeholder expectations}

The shift in the authority for issuing mining licences and permissions from central government to local governments as a result of Indonesia's regional autonomy laws forces mining companies to engage local communities in consultation with, and through, local governments (Cesare and Maxwell, 2003). In addition, the Indonesian mine reclamation and closure regulations require that stakeholder engagement occurs as part of the mine closure planning process. While the regulations do not define the nature or extent of stakeholder input, Cesare and Maxwell (2003) note that the intent of this requirement is to facilitate the transition of a local economy from mineral dependence to post-mining economic development in other areas.

Prior to decentralisation and the introduction of the Indonesian regulation regarding mine reclamation and closure, stakeholder engagement in closure planning was conducted on a voluntary basis at the discretion of the mining company. As part of its closure planning process for the Mesel gold mine, which commenced prior to the introduction of the regulations, PT NMR is striving towards capacity building with initiatives coming from a Community Consultative Council (CCC), but the company has found that additional community expectations and requirements are also being voiced in other ways. This has occurred for a number of reasons such as people not feeling that they have had an opportunity to contribute to the CCC or being new to the area. PT NNT's closure planning personnel record community expectations aired during mine closure plan consultation sessions and accommodate these where possible, but they also recognise that community expectations of closure outcomes are likely to continue to change due to dynamics in the community and the fact that mine closure is unlikely to occur for at least another 16 years. Consequently, they are striving to ensure that the level of effort put into stakeholder engagement and community development for closure is commensurate with the status the project.

PT KEM also chose to negotiate directly with key community and government representatives to define workable outcomes agreed by all parties. Central to this consultative process was the Kelian Mine Closure Steering Committee (KMCSC) which comprised representatives from PT KEM, Rio Tinto, the community, government agencies and NGOs (McGuire, 2003a; Rio Tinto, 2004). In addition to the KMCSC, a Community Advisory Group was established in relation to the long term monitoring and maintenance of the site (Rio Tinto, 2004). The KMCSC was chaired jointly by the Bupati (head) of the regional West Kutai government and the President Director of PT KEM, and developed a charter, a website and evaluation criteria to ensure accountability and transparency. The group met on a quarterly basis to examine closure options in accordance with criteria outlined in the charter and endorsed sustainable solutions and standards that have support from government, community and the mine (McGuire, 2003b). 


\section{Conclusion}

Government direction and guidance on mine closure has become stronger in Indonesia in recent years, and there have been several success stories including PT NMR and PT KEM. However, regulatory guidance is still lacking in many areas. For example, there is still a need for more detailed guidance on the way in which the GoI expects mining companies to address a number of key factors, including developing success criteria, engaging with community and other stakeholders, determining post-mining land uses and community economic sustainability. There is also a need for clarity regarding the roles and authority of the various levels of government in relation to mine closure, capacity building within government, and improved communication between different levels of government and between government and mining companies. However, the recent issuance of mine reclamation and closure regulations and decrees are well intended and, if managed well, will assist in improved environmental standards in post mining areas.

Despite strengthening government guidance on mine reclamation and closure, the onus remains on the mining company to develop closure plans appropriate to the nature of the mining operation and its environmental, social, economic and political setting. These plans should be developed from an early stage of project development and aim to leave a positive environmental and community legacy that also reduces technical and reputational risk for the mining company. This can be challenging in a country as environmental, socially and politically diverse as Indonesia, but the likelihood of success increases as mining companies implement best closure practices and commit to continual improvement.

\section{Acknowledgements}

The authors thank Greg Morris (Newcrest Mining Limited) and the technical reviewers for their comments on this paper.

\section{References}

Anon (2011) An overview of spatial policy in Asian and European countries: Indonesia. Available at: http://www.mlit.go.jp/kokudokeikaku/international/spw/general/indonesia/index_e.html. Accessed 10 April 2011.

ANZMEC and MCA (2000) Australian and New Zealand Minerals and Energy Council and Minerals Council of Australia. Strategic Framework for Mine Closure. Australian and New Zealand Minerals and Energy Council and Minerals Council of Australia, $22 \mathrm{p}$.

Bureau of East Asian and Pacific Affairs (2011) Background note: Indonesia. Available at: http://www.state.gov/r/pa/ei/bgn/2748.htm. Accessed 3 April 2011.

Cesare, P. and Maxwell, P. (2003) Mine closure legislation in Indonesia: the role of mineral industry involvement, Natural Resources Forum 27, pp.42-52.

Chamid, C., Sulistijo, B. And Crispin, G. (2000) Sustainable solution for post mine closure in gold mine (PT KEM's case for local mining community). Available at: commdev.org/content/document/detail/1360/. Accessed 4 April 2011.

Hentschel, T., Hruschka, F. and Priester, M. (2002) Global report on artisanal \& small-scale mining. International Institute for Environment and Development and World Business Council for Sustainable Development. Report No. 70. 67p.

Limbong, D., Kumampung, J., Rimper, J., Arai, T. and Miyazaki, N. (2002) Emissions and environmental implications of mercury from artisanal gold mining in north Sulawesi, Indonesia. The Science of the Total Environment. Vol. 302, Issues 1-3, pp. 227-236.

McGuire, G. (2003a) Managing mine closure risks in developing communities - a case study, Kelian Equatorial Mining, Indonesia. A paper presented at the Mining Risk Management Conference, Sydney, NSW, 9-12 September 2003, 10 p.

McGuire, G. (2003b) Development of social closure standards at Kelian Equatorial Mining. A paper presented at the Workshop on Sustainable Mine Closure, Adelaide, SA, 23-24 October 2003.

Newcrest Mining Limited (undated) Mercury on Halmahera. Available at: http://www.newcrest.com.au/upload/mercury_on_halmahera.pdf. Accessed 16 April 2011.

Newmont (2010) Minahasa area ready for hand over. Available at: http://www.newmont.com/features/our-environmentfeatures/Minahasa-Area-Ready-for-Hand-Over. Accessed 28 April 2011.

Rio Tinto (2004) Kelian mine closure. Available at: http://www.riotinto.com/media/news_4414.asp. Accessed 16 April 2011. 
Soeprapto, P. (2011) Government Regulation PP78/2010 and its (perceived potential) impact to the mining industry. Presentation to a Petromindo seminar on PP78/2010, January-February 2011.

Sullivan, B. (2011) Reclamation and post mining activities - excessive and unrealistic regulation. Coal Asia magazine, April 2011 issue, 5 p. 